\title{
What's in a Name?: Geographical Indicators, Legal Protection, and the Vulnerability of Zinfandel
}

Stephen M. Jurca

Indiana University Maurer School of Law, sjurca@indiana.edu

Follow this and additional works at: https://www.repository.law.indiana.edu/ijgls

Part of the Agriculture Law Commons, Food and Drug Law Commons, International Law Commons, and the International Trade Law Commons

\section{Recommended Citation}

Jurca, Stephen M. (2013) "What's in a Name?: Geographical Indicators, Legal Protection, and the Vulnerability of Zinfandel," Indiana Journal of Global Legal Studies: Vol. 20 : Iss. 2 , Article 30.

Available at: https://www.repository.law.indiana.edu/ijgls/vol20/iss2/30

This Note is brought to you for free and open access by the Law School Journals at Digital Repository @ Maurer Law. It has been accepted for inclusion in Indiana Journal of Global Legal Studies by an authorized editor of Digital Repository@Maurer Law. For more information, please contactrvaughan@indiana.edu.

\section{$\Psi$}

JEROME HALL LAW LIBRARY

INDIANA UNIVERSITY

Maurer School of Law
Blooming ton 


\title{
What's in a Name?: Geographical Indicators, Legal Protection, and the Vulnerability of Zinfandel
}

\author{
STEPHEN M. JURCA ${ }^{*}$
}

\begin{abstract}
This note explores the issues countries face when one party allegedly takes unfair economic advantage of foreign competitors in an increasingly global market by broadly interpreting international product labeling laws in its favor. The United States' widespread use of the term "champagne" in its domestic sparkling wine industry is just one example of how "genericide"-the process by which a popular brand name becomes so commonly used that the term is no longer protected by intellectual property law-negatively affects trade relations and hampers economic growth.

This note focuses on the dangers of genericide in the marketplace, most specifically, the international wine trade, and looks to other industries and previous remedies that have successfully been used, for guidance on what steps can be taken to minimize trade conflicts. Throughout the note, it is shown that it will be economic factors, local advocacy, and long-term incentives that will create the impetus necessary for change in this otherwise stagnant area of international law.
\end{abstract}

\section{INTRODUCTION}

As international trade establishes powerful bilateral and multilateral economic relationships among various countries, the standardization of intellectual property laws has led to significant debate over whether geographically specific denotations in product labeling should be protected, and if so, to what extent. ${ }^{1}$ This note looks

* Executive Notes Editor, Indiana Journal of Global Legal Studies; J.D. 2013, Indiana University Maurer School of Law. I would like to thank my good friend, Louise Barrett, for her patience and assistance throughout the writing and editorial processes.

1. For an in-depth discussion of the state of geographical indication law, see generally Justin Hughes, Champagne, Feta, and Bourbon: The Spirited Debate About Geographical

Indiana Journal of Global Legal Studies Vol. 20, Issue 2 (2013)

(C) Indiana University Maurer School of Law 
at the United States' and European Union's differing approaches to geographical protection for alcoholic beverages and the problems associated with the continuing use of generic alcohol labeling in the United States.

This note focuses primarily on the United States' failure to adopt strict labeling standards that are used throughout the European Union. However, the concepts addressed by the U.S.-EU examples in this note are relevant to trade alliances that are much broader in scope than just those associated with alcohol. The United States' refusal to protect France's intellectual property rights in the term "champagne," for example, is only one of several examples mentioned. The arguments made in this note can be extended to an array of economic issues and products. The consequences of disharmony among multinational intellectual property laws are potentially vast given the volume of trade and consumption of products between the European Union and the United States. ${ }^{2}$

Part I summarizes the protections the United States gives foreign products with geographical indications, both as a result of World Trade Organization (WTO) requirements and U.S. statutory law. Part II investigates the United States' use of generic, geographical terms in its domestic wine industry and looks at the threats generics pose for producers and consumers alike. Part III looks at the issues the United States faces in the global wine market and how past remedies could be applied to future problems in the international market. Part IV makes the case for the United States to initiate more proactive cooperation with other countries in an effort to protect its own uniquely American goods, which have yet to receive the reciprocal intellectual property protection they merit.

Indications, 58 HASTINGS L.J. 299 (2006). Professor Hughes' law review article does an exceptional job to describe the laws I discuss in this paper and uses, like this note, many of the same salient examples that are most commonly used in this subject matter.

2. Donald A. Hodgen, DeP'T OF CoMmerCe, U.S. WINE INDUSTRY - 2008, at $3-4$ (2008), available at http://www.trade.gov/td/ocg/wine2008.pdf (discussing the volume of trade between the United States and other countries); see also Press Release, Wine Institute, 2011 California Wine Shipments Within U.S. Reach All-Time High: U.S. Is World's Largest Wine Market (Mar. 22, 2012), http://www.wineinstitute.org/resources/ pressroom/03222012; Press Release, Wine Institute, 2011 U.S. Wine Exports, 90 Percent From California, Reach New Record Of $\$ 1.4$ Billion (Feb. 16, 2012), http://www.wine institute.org/resources/pressroom/02162012. 


\section{Legal Protections AfForded to Foreign Products in the U.S. MARKET}

\section{A. Multilateral Protections in the World Trade Organization}

The Agreement on Trade-Related Aspects of Intellectual Property Rights (TRIPS) governs intellectual property law among WTO members, including the United States. ${ }^{3}$ TRIPS Article 22 protects members' rights in "geographical indications,"-commonly referred to as "GIs"-which are "indications which identify a good as originating in the territory of a Member, or a region or locality in that territory, where a given quality, reputation or other characteristic of the good is essentially attributable to its geographical origin."' Such protection provides WTO members the legal means to prevent the producers of certain goods from misrepresenting the true geographical origin of their products. ${ }^{5}$ For example, a U.S. dairy cannot label a product as "Roquefort" cheese ${ }^{6}$ if it was not produced ${ }^{7}$ or packaged 8 in the Community of Roquefort, France, as French law also requires, because the producers would mislead

3. Agreement on Trade-Related Aspects of Intellectual Property Rights, Apr. 15, 1994, Marrakesh Agreement Establishing the World Trade Organization, Annex 1C, 33 I.L.M. 1197 [hereinafter TRIPS].

4. Id. art. $22(1)$, at 1205 .

5. Id. art. $22(2)($ a), at 1205 .

6. U.S. law requires Roquefort cheese to be inoculated with the Penicillium roquefortii mold-a mold that is unique to the caves of Roquefort, Department of Aveyron, France. 21 C.F.R. $\S 133.184$ (2011). In addition, the U.S. Trademark Act also provides that U.S. Registration No. 571,798 gives the mark "Roquefort" the legal indication that "the cheese has been manufactured from sheep's milk and cured in the caves of the Community of Roquefort (France)." See Office of the Administrator for Policy and External AffairsGeographical Indications (GI) Protection, http://www.uspto.gov/ip/global/geographical/pro tection/index.jsp (last visited Feb. 23, 2013).

7. Article 1, Loi 2005-120 du 17 mai 2005 de modificatif relatif à l'appellation d'origine contrôlée " Roquefort " [Law 2005-120, Modifying the Naming of Controlled Origin of "Roquefort"] JOURNAL OFFICIEL DE LA RÉPUBLIQUE FRANÇAISE [J.O.] [OFFICIAL GAZETTE OF FRANCE] May 25, 2005, at 9023, http://www.legifrance.gouv.fr/affichTexte. do?cidTexte=JORFTEXT000000627817\&dateTexte=\&categorieLien=id (citing Articles 1 and 2, Loi 2001-21 du 22 janvier 2001 de Relatif à l'appellation d'origine contrôlée " Roquefort ", [Law relating to the naming of the controlling origin of "Roquefort"] JoURNAL OfFiciel De la RÉPUblique Française [J.O.] [OFfiCial GazeTte of FranCE] Jan. 25, 2001, at 1283, http://www.legifrance.gouv.fr/affichTexte.do?cidTexte=JORFTEXT0000007 $68632 \&$ date $T$ exte $=\&$ categorieLien $=\mathrm{id}$ )

8. Article 6, Loi 2001-21 du 22 janvier 2001 de Relatif à l'appellation d'origine contrôlée " Roquefort ", [Law relating to the naming of the controlling origin of "Roquefort"] JOURNAL OFFICIEL DE LA RÉPUBLIQUE FRANÇAISE [J.O.] [OFFICIAL GAZETTE OF FRANCE] Jan. 25, 2001, at 1283, http://www.legifrance.gouv.fr/affichTexte.do?cidText $\mathrm{e}=$ JORFTEXT000000768632\&fastPos $=4 \&$ fastReqId $=1058036993 \&$ categorieLien $=i d \&$ oldA ction=rechTexte. 
consumers as to the cheese's true geographical origin (in this hypothetical, the United States). This hypothetical dairy could not meet the TRIPS labeling requirement while using the name "Roquefort," even if the cheese label, for example, were qualified, saying "American Roquefort," "Roquefort: Product of the USA," or "Roquefort-type cheese."

TRIPS Article 23 gives wines and spirits additional labeling protections. Under these guidelines, producers may not use a GI that does not reflect a protected wine or spirit's true origin "even where the true origin of the goods is indicated or the geographical indication is used in translation or accompanied by expressions such as 'kind', 'type', 'style', 'imitation' or the like."9 This additional protection prevents, for example, U.S. vintners from producing a Rhône wine and labeling it as "Rhône wine," "American Rhône," or even "Rhône-style wine"10 in an effort to capitalize on the French Rhône appellation's reputation.

Despite the strict labeling protections in TRIPS Article 23, producers falling under an exception specified in TRIPS Article 24 may still label products in a liberal manner. What is perhaps the most important exception to TRIPS Article 23 is one that is exceptionally favorable to producers that operate outside the confines of a protected GI's boundaries. Producers in a particular country can label goods, like a wine, with a GI label from another country so long as either (1) that particular GI has been continuously used in that country for at least ten years preceding April 15, 1994, or (2) the GI had been used in "good faith" preceding that same date. ${ }^{11}$ This grandfather clause allows certain labels to use otherwise prohibited GIs; it is this exception that allows California to produce "champagne." This exception gives diminished protection to long-standing, well-recognized appellations because of the increased chance that producers have used those GIs in their labeling practices before the specified cut-off date came into effect.

TRIPS Article 24 contains other exceptions that undermine the efficacy of the TRIPS protective framework. For instance, the Article denies coverage to GIs that, within their countries of origin, are not legally protected or have fallen into "disuse." 12 Furthermore, the TRIPS framework states that "Nothing in this Section shall require a Member to apply its provisions in respect of a geographical indication of any other Member with respect to goods or services for which the relevant indication is identical with the term customary in common language as

9. TRIPS, supra note 3 , art. 23(1), at 1205 .

10. Rhône is both a type of wine and the name of a region of France (specifically the Rhône Valley region). "Rhone" (without circumflex) is also an example of a GI protected by U.S. law. 27 C.F.R. $\$ 4.24$ (c)(3) (2012).

11. TRIPS, supra note 3 , art. 24(4), at 1206.

12. Id. art. 24(9), at 1207 . 
the common name for such goods or services in the territory of that Member." 13 Therefore, if a country were to unilaterally deem that a specific GI was, in fact, a generic term, ${ }^{14}$ then TRIPS would not protect that GI at all. This allows, for example, a country like the United States to call its sparkling wine "champagne" if it deems the term "champagne" to be generic in common use. When an offending country asserts an affirmative defense to infringement of another country's GI, tolerance of such an exception might create tension between countries that have differing views on what constitutes a generic name.

\section{B. Protections Under U.S. Law}

U.S. law provides numerous protections to a variety of GIs. For wines, the United States currently recognizes "generic, semi-generic, and non-generic designations of geographical significance." 15 Some wines, like sake, that once had geographical significance-an origin of widely accepted and particular prominence-are now only protected to the extent that they are produced in a particular fashion, regardless of actual origin. ${ }^{16}$ Producers may call their products by these generic names so long as the products conform to the relatively lax statutory standards of identity. Sake, a rice wine traditionally from Japan, for example, must merely be a "wine . . produced from rice in accordance with the commonly accepted method of manufacture of such product."17

Unlike their generic counterparts, nongeneric designations for wine, such as Bordeaux Blanc, that are uniquely associated with a definable point of origin and are distinguishable from other wines, are strictly protected terms enforced by statute. Nongeneric products must carry labels that certify production with the delineated perimeters for that particular goods' true origin. Furthermore, nongeneric names can be either "distinctive" or "not distinctive" in nature. A distinctive, nongeneric designation is indicative of the estate or commune from where a wine originates. Examples include Bordeaux Rouge, Pommard, and Liebfraumilch. ${ }^{18}$ These distinctive labels can only be carried on goods that originate from a highly-specified area. Nondistinctive,

13. Id. art. 24(6).

14. This phenomenon of a brand name turning into a common noun-"genericide"-occurred in the United States with the use of the brand name "aspirin" in common parlance when referring to generic pain killers. See 2 J. THOMAS MCCARTHY, MCCARTHY ON TRADEMARKS AND UNFAIR COMPETITION 12.8.1 to 8.2 (4th ed. 2009) [hereinafter MCCARTHY].

15. 27 C.F.R. $\$ 4.24$ (2012).

16. Id. $\S 4.24(\mathrm{a})(2)$.

17. 27 C.F.R. $\$ 4.21(f)(5)(2012)$.

18. 27 C.F.R. $\$ 4.24$ (c)(3) (2012). 
nongeneric designations are more generalized geographical labels, but are nonetheless protected by law. "Napa Valley," "New York State," and "French" are all examples of nondistinctive, nongeneric labels. ${ }^{19}$ This nondistinctive, nongeneric classification prevents, for example, a wine produced in California from being labeled as "French," or a wine produced in Los Angeles from being called "Napa Valley-style." Because the United States provides heightened protection to nongeneric products, producers in well-known appellations desire nongeneric designations in order to prevent competitors from outside the GI region from profiting from the regions' reputation.

Not all designations, however, fall neatly into the generic-nongeneric binary. The United States recognizes a third class of geographical designations deemed "semi-generic," which "may be used to designate wines of an origin other than that indicated by such name only if there appears in direct conjunction therewith an appropriate appellation of origin disclosing the true place of origin of the wine." 20 Many highly recognizable wine names are found in this category, including Burgundy, Champagne, ${ }^{21}$ Chianti, Port, and Sherry. ${ }^{22}$ Wines in this category "currently have 'geographical significance' but also 'designate a class or type of wine." 23 A California vintner, therefore, may use the label "California Port" because he has produced a "class" of wine while clearly designating the wine's true origin (i.e., California).

Arguably, champagne is the most recognizable and disputed semigeneric wine designation in the United States. In the United States, the statutory definition of champagne is rather broad:

Champagne is a type of sparkling light wine which derives its effervescence solely from the secondary fermentation of the wine within glass containers of not greater than one gallon capacity, ${ }^{24}$ and which possesses the taste, aroma, and other characteristics attributed to

19. $I d . \S 4.24(\mathrm{c})(2)$. The statute refers to "not distinctive designations" but I have chosen to use the term "non-distinctive" to improve readability.

20. Id. § 4.24(b)(1).

21. In France, "champagne" has been protected as a name not available for use in the public domain since the late nineteenth century; however, French courts could not enforce French laws outside their jurisdiction. Kolleen M. Guy, Oiling the Wheels of Social Life, 22 FRENCH HIST. STUD. 211, 226 (1999).

22. 27 C.F.R. § 4.24(b)(1) (2012).

23. Carol Robertson, The Sparkling Wine War: Pitting Trademark Rights Against Geographic Indications, 18 BUS. L. TODAY 19, 21 (2009), available at http://apps.american bar.org/buslaw/blt/2009-05-06/robertson.shtml.

24. Under U.S. law, secondary fermentation of champagne cannot take place in a container greater than a three-liter Jeroboam bottle. 
champagne as made in the Champagne region of France. ${ }^{25}$

Sparkling wines that possess the "taste, aroma, and other characteristics" of champagne, but that do not otherwise conform to the statutory definition, may still be labeled as "champagne style," 26 "champagne type,"27 or even "American champagne." 28 Because of these lenient labeling standards, U.S. producers may produce champagne-like sparkling wine and label it as champagne (with the caveat that the product indicates its true place of origin) despite the wine not originating in Champagne, France. Shockingly, a vintner may do this without following traditional champagne-making methods (méthode champenoise). ${ }^{29}$

Though the United States has mechanisms to protect foreign alcohol GIs from domestic name poaching, the Administrator of the Alcohol and Tobacco Tax and Trade Bureau, an agent of the Department of the Treasury, ${ }^{30}$ decides which classes of wine are generic, semigeneric, or nongeneric. ${ }^{31}$ As an appointed official, ${ }^{32}$ the Department's Administrator is guided by the political and administrative policies of the current presidential administration. GI protection is therefore subject to political ebbs and flows and, should future harmonization of intellectual property laws in wine be contemplated, could be changed at the discretion of the Treasury Administrator or a given president.

\section{GENERICIDE AND ITS EFFECT ON THE INDIVIDUAL CONSUMER}

\section{A. The Genericide Phenomenon and the Difficulty in Preventing It}

Intellectual property laws, including the TRIPS framework, typically exclude generic product names from any umbrella of legal protection. ${ }^{33}$ Sake, for example, was originally a term of geographical

\footnotetext{
25. 27 C.F.R. § 4.21(b)(2) (2012).

26. Id. $\$ 4.21(\mathrm{~b})(3)(\mathrm{i})(\mathrm{A})$.

27. Id. $\$ 4.21(\mathrm{~b})(3)(\mathrm{i})(\mathrm{B})$.

28. Id. $\S 4.21(\mathrm{~b})(3)(\mathrm{i})(\mathrm{C})$.

29. Vintners can produce similar products using what is called the "Charmat Process," by which wine undergoes secondary fermentation in bulk rather than individually by bottle. JANCIS ROBINSON, THE OXFORD COMPANION TO WINE 157 (3d. ed. 2006).

30. 27 C.F.R. $\$ 1.10(2012)$.

31. 27 C.F.R. $\$ 4.24(\mathrm{a})(1)(2012)$.

32. The Administrator is appointed by the Secretary of the Treasury. See John J. Manfreda, ALCOHOL \& TOBACCO TAX \& TRADE BUREAU, http://www.ttb.gov/about/johnm. shtml (last updated Apr. 18, 2012).

33. See MCCARTHY, supra note 14 , at 12-9.
} 
significance; ${ }^{34}$ the rice wine had its historical origin in Japan. Now, that term refers to a general type of product (i.e., rice wine) rather than the place whence the product originally came (i.e. Japan). This product term entered the public domain upon the product's name becoming disassociated with its area of origin, in that although sake has historic roots in Japan, it may not be assumed that it is now always manufactured in Japan. As such, intellectual property law deems that (and similarly-situated terms) to be ineligible for protection.

Bayer Co. v. United Drug Co. ${ }^{35}$ is a leading case in the United States examining the phenomenon of genericide ${ }^{36}$ - the process by which a brand name becomes a common noun that is not protected, but rather is in the public domain. In this case, Bayer began to market a new painkiller, acetyl salicylic acid, under the trade name "aspirin." Consumers subsequently referred to this new class of painkillers, generally, as "aspirin." Because consumers called this class of acetyl salicylic acid painkillers by the name "aspirin"-regardless of the manufacturer and to the point that the term "aspirin" denoted any type of comparable painkiller-the trade name entered the public domain, rendering "aspirin" a generic term available for public use. ${ }^{37}$ In his opinion, Judge Learned Hand allowed Bayer's competitors to market their similarly-manufactured painkillers under the term "aspirin." 38 The holding denied Bayer the trade name protection it pled for, despite the company's initial conception and marketing of the name for its product.

Genericide threatens companies, like Bayer, that are the first to market and develop customer loyalty for a product before competitors have an opportunity to offer similar goods. ${ }^{39}$ Genericide occurs if a significant length of time lapses between the popularization of a product's name, during which the public uses the trade name as a common name for a general class of product, and the introduction of competitors into the market. ${ }^{40}$ If this happens, competitors may then adopt the original name as a generic without consequence. ${ }^{41}$ The goal of intellectual property law protection is to help prevent genericide by

34. 27 C.F.R. $\$ 4.24(\mathrm{a})(2)(2012)$.

35. Bayer Co. v. United Drug Co., 272 F. 505 (S.D.N.Y. 1921).

36. See MCCARTHY, supra note 14, at 12-8.1.

37. See Bayer, 272 F. at 514.

38. Id. at 515.

39. See MCCARTHY, supra note 14 , at 12-8.2.

40. Aspirin was patented in the United States in 1900 (U.S. Patent No. 644,077 (filed Aug. 1, 1898)), but the patent was cancelled in 1919 as a consequence of war reparations stemming from Article 298 of the Treaty of Versailles. Treaty of Versailles art. 298, June 28, 1919, 1919 U.S.T. Lexis 42.

41. Deborah J. Kemp \& Lynn M. Forsythe, Trademarks and Geographical Indications: A Case of California Champagne, 10 CHAP. L. REV. 257, 267 (2006). 
preventing competitors from taking advantage of trade names to the detriment of the owner.

Retroactive attempts to extend intellectual property law to geographical designations that have lost their significance throughout the world have proven problematic. 42 One scholar notes that a geographical designation can be "merely a sentimental reference to the days of yore. . . While individual nations may advocate it, well-reasoned law is not prepared to turn back the hands of time."43 Retroactive protection of now-generic geographical designations would have significant consequences for companies using those labels. Such protection would require exceptional changes to product names, sales, and marketing. ${ }^{44}$ Imagine, for example, if the Ceské Budějovice (Budweis) GI, the original Czech region producing the Budweis style of beer, were granted an exclusive right to the use of the "Budweiser" name in the United States. Anheuser-Busch, the U.S. brewer of Budweiser beer, would be forced to abandon the trade name that the company cautiously guarded and meticulously created a brand for. ${ }^{45}$ Anheuser-Busch, and other companies facing similar challenges, would undoubtedly fight tooth-and-nail to prevent such laws from being adopted. Although the Budweiser example-one of a corporation with a highly-recognizable, copyrighted trade name-is extreme, the hypothetical reflects the difficulty any producer will have in facing a compromise or change to property rights, no matter how simple the change or compromise may appear to be. ${ }^{46}$ Indeed, applying this standard to even a small product segment of any international market would have staggering financial and economic consequences. ${ }^{47}$ Proposals that the "protected GI of one country is never generic in another" may be easy to suggest, but would be difficult to implement, because the economic consequences for many producers would be so great that these corporations would undoubtedly challenge this proposal with all available resources. ${ }^{48}$

When multiple political bodies attempt to develop a unified meaning of the word "generic", difficulties in creating such a definition will undoubtedly arise. The Commission of the European Communities

42. See id. at 288.

43. Id.

44. See Elizabeth Barham, Translating Terroir: The Global Challenge of French AOC Labeling, 19 J. RURAL STUD. 127, 128 (2003).

45. See id. at 129.

46. See id.

47. Frances G. Zacher, Pass the Parmesan: Geographic Indications in the United States and the European Union-Can There Be Compromise?, 19 EMORY INT'L L. REV. 427, 462 (2005).

48. See id. at 448 . 
offered guidance, however, on how to create a consistent standard and suggested factors countries might look to when evaluating whether a product is generic. The Commission did this in an opinion determining whether "Feta," the name for a traditional Greek cheese, was a generic term. ${ }^{49}$ The committee tasked with this assessment unanimously concluded that Feta was a nongeneric term. ${ }^{50}$ The opinion reasoned that "production and consumption of 'Feta' are heavily concentrated in Greece" and that "the original Greek product is dominant on the Community market." 51 In fact, in 2002, when the opinion was issued, Greece accounted for 60 percent of EU production of, ${ }^{52}$ and 73 percent of EU consumption of, 53 the cheese. The Commission considered the primary place of origin and consumption of Feta to be critical when making its determination.

The Committee also noted that "the designation 'Feta' could not be said to have become generic since the word is not used as a common name. In consumers' perception, the name 'Feta' always evokes a Greek origin and therefore is not something which has become a common name and hence generic in the Community." 54 The opinion also recognizes the Greek "ancestral tradition" 55 _the relationship between natural and human factors, particularly the "traditional production method," which gives Feta its "remarkable international reputation." 56 The Committee found that because there was no allusion to a common name and because there was a tendency to imply a Greek origin, the term "Feta" should be added to the register of protected designations of origin and GIs in the European Community. ${ }^{57}$

\section{B. Generics and the Reality of Product Homogeneity}

There is a deliberate trend toward the homogenization of goods and a drive toward product consistency. Product homogeneity is prevalent,

49. See Commission Regulation 1829/2002, 2002 O.J. (L 277) 12 (EC).

50. See id. at para. 29.

51. Id. at para. 30.

52. See id. at para. 24 .

53. See id. at para. 25.

54. Id. at para. 30 .

55. Id. at para. 36 .

56. Id.

57. See id. at art. 1. The United States does not give protection to the term "Feta." See BRUCE A. BaBCOCK \& ROXANNE Clemens, Midwest AgRibusiness TRADE ReS. AND INFO. CTR., IOWA ST. UNIV., MATRIC BRIEFING PAPER 04-MBP 7, GEOGRAPHICAL INDICATIONS and Property Rights: Protecting Value-Added Agricultural Products 36 (2004), available at $\mathrm{http}: / / \mathrm{www}$. card.iastate.edu/publications/dbs/pdffiles/04mbp7.pdf. 
for example, in the production of cheese.58 Large corporations have taken over in cheese production to the detriment of small, traditional dairies. ${ }^{59}$ Critics accuse large corporations of aiming to produce an "everyday". cheese that is "creamy, tender and bland" and palatable to everybody. 60 This process of product homogenization threatens "local traditions, small scale production by hand, [and] the use of tasty raw milk,"61 and endangers, as one cheese enthusiast remarks, "the richness [that] comes in the originality, even in the imperfections."62 Another cheese expert notes that "eventually everything's going to taste the same-all because of profit," 63 a lamentation that seems increasingly unheard as the popularization of industrial cheese production processes increases.

The wine industry faces similar concerns of product quality convergence. Critics of mass-produced wine fear that commercial processes create goods that lack "soul" and contribute to the industry's divergence from the days when winemaking was an art to a new era where it is a computer-driven science. ${ }^{64}$ Proponents of the GI system remind consumers that "Pennsylvania pinot noir is only worth drinking if it tastes of Pennsylvania rather than trying to duplicate a California style."65 The creation of "distinct regional identities" through the GI system contributes to the diversity of products in the market ${ }^{66}$ and, arguably, to the quality as well.

In times like the present, when consistency and predictability are often prized characteristics in the food industries, companies base advertising campaigns on romanticized notions of "tradition" and "terroir" (regional traits), ${ }^{67}$ despite increased uniformity in products. Ironically, as one author points out, "French consumers apparently want to believe they're buying the same gutsy, distinct cheese grandpa ate, but they don't want to experience the guts or the character."68

58. See Jacqueline Friedrich, The French Move Their Cheese-Down-Market, WaLL ST. J., June 20, 2000, at A24, available at http://www.jacquelinefriedrich.com/blog.htm?post $=590888$.

59. See id.

60. Id.

61. See A Cheesy Tale, ECONOMIST, Sept. 29, 2007, at 48.

62. Elaine Sciolino, If Rules Change, Will Camembert Stay the Same?, N.Y. TIMES, June 20, 2007, at F1.

63. Id.

64. See Paul Levy, Mondavi Moves In, and the French Cry Foul, WALL ST. J., June 14, 2000 , at A24.

65. Eric Asimov, All Over America, Wines Search for Identity, N.Y. TIMES, Jan. 31, 2007, at F7.

66. See id.

67. See Friedrich, supra note 58.

68. Id. 
Regardless of the authenticity or origin of the products consumers purchase, there is an "ongoing construction of a collective representation of the past through food that perhaps largely unconscious." 69

\section{Consumer Psychology and Preferences at the Market}

Often, geographical designations "have a certain drawing power or cachet which makes consumers wish to be associated with it."70 Though the value of a protected GI lies in the quality associated with the protected good, GIs "also generate their utility through evocative and aesthetic uses"71 and through the preservation of "certain historical and cultural purit[ies] of production."72 Consumers' emotions and seemingly irrational preferences ${ }^{73}$ often influence purchasing behavior, ${ }^{74}$ and preferences can be muddied by preconceived ideas of product quality. ${ }^{75}$

For example, champagne evokes luxury and opulence. Sparkling wine, on the other hand does not; rather, the term may have the opposite effect and create a perception of diminished quality. ${ }^{76}$ Because the average consumer purchases champagne (and other luxury goods) infrequently, there is a hurdle in educating consumers as to what constitutes quality among those products. ${ }^{77}$ Where consumption is infrequent, as in the case of champagne, consumers "inflate the memory" of that product experience, and associate that memory with that specific product. ${ }^{78}$ Consequently, for future occasions, such as a wedding, consumers will be more likely to buy the product with a "champagne" label, rather than the similar "sparkling wine" because they have enjoyed it in the past and want to create similar positive

69. Barham, supra note 44, at 132.

70. Oskari Rovamo, Monopolizing Names? The Protection of Geographical Indications in the European Community 11 (Aug. 2006) (unpublished pro gradu thesis, Helsinki University) (on file with Faculty of Law Library, Helsinki University).

71. Id. at 12.

72. Id. at 14 .

73. Contemporary economists assume that consumer preferences are inherently self-interested and, therefore, inherently rational. See THOMAS SOWELL, BASIC ECONOMICS 70 (3d. Ed. 2007). ("Under any economic or political system, people can make their choices only among the alternatives actually available-and different systems present different alternatives.")

74. Rovamo, supra note 70 , at 11 .

75. See Lawrence M. Fisher, Can California Sparkling Wine Taste Like Champagne? The Quest Goes On, N.Y. TIMES, Dec. 25, 1991, at 29.

76. Id.

77. $I d$.

78. $I d$. 
memories. ${ }^{79}$ Even though many people would prefer the typically sweeter sparkling wine to the more nuanced French champagne, ${ }^{80}$ otherwise uninformed consumers will often stick to what they "know."81 It is this confusion that makes the "champagne" label so valuable: scores of consumers may believe they have enjoyed traditional French champagne when, in fact, sparkling wine (perhaps a prosecco or cava) was uncorked. This mistaken belief increases the probability the average consumer will purchase a sparkling wine with a champagne label regardless of the product's actual place of origin.

Because of the psychological preference for the "high-quality" luxury good over its generalized and "common" equivalent, producers within the boundaries of a region of geographical significance have an incentive to exclude perceived imitators from the market and monopolize use of the valuable locale's name. GIs "hold the potential of re-linking production to the social, cultural, and environmental aspects of particular places, further distinguishing them from anonymous mass-produced goods, and opening the possibility of increased responsibility to place." 82

To create this link to a good's place of origin, producers often talk about the concept of terroir as a feature that captures regional idiosyncrasies, generally of the earth. Terroir denotes "an area or terrain, usually rather small, whose soil and microclimate impart distinctive qualities to food products." 83 A terroir can have a reputation to produce a grand cru (exceptional wine), and a wine can also be said to have the goût, or taste, of its terroir. ${ }^{84}$ The European Union, having an interest in protecting its agricultural sector, strongly supports the international recognition of GIs, but justifies this advocacy on the concept of terroir and a product's uniqueness, rather than admitting to economic protectionism. The European Union restricts GI property rights to specific regions, ${ }^{85}$ which have been meticulously delineated. 86 The United States, on the other hand, not having such a developed system, chooses to grant trademarks and other intellectual property

79. Frank J. Prial, Wine Talk, N.Y. TimeS, June 9, 1993, at C8 [hereinafter Prial, Wine Talk].

80. $I d$.

81. Id.

82. Barham, supra note 44 , at 129 (emphasis added).

83. Id. at 131 .

84. Id.

85. Id. at 129 .

86. For a brief example of the difficulties associated with defining and joining a specific appellation, see generally Sarah Nassauer, Demand for Champagne Gives Peas a Chance-Small French City Gets Another Shot at Joining Lucrative Appellation, WALL ST. J., Dec. 14, 2007, at B1. 
rights to individuals (or corporations) ${ }^{87}$-rights that can be sold or transferred-for products that can be named, often without respect to their place of origin.

A protected GI arguably informs the consumer as to the processes, tradition, and history of the product. ${ }^{88}$ However, even terroir advocates agree that "the character of a product is determined by terroir, whilst man determines quality."89 For opponents of terroir, because man determines quality (and thereby a large component of the product's character), terroir is an insufficient justification for guarding the use of an otherwise generic name. This criticism of terroir is reflected in modern intellectual property law: terroir is used increasingly seldom as a justification for legal protection, while broader GIs are protected "solely on the basis of a certain reputation among consumers."90

In France, the culture of terroir is so robust that even people are said to reflect the terroir of their upbringing. ${ }^{91}$ In the United States, there is an appreciably diminished cultural attachment to a person's terroir, so skeptics can reasonably question why residents of the United States should be bound to a cultural system that is not appreciated within their own borders. ${ }^{92}$ This culture of terroir as it relates to both people and products did not translate well from the Old World to the New. Although people in the United States often have pride in their regions of upbringing, the Old World justifications for protectionism and regionalism fail to accord with the New World mentality that seeks to include foreign ideas and processes.

The United States exemplifies the meaning of a "derivative society"- "immigrants from around the world came to the United States with their own customs and frequently adopted familiar names from their native countries for products and their locations."93 Just as many people are unlikely to expect Swiss cheese to always be a product of Switzerland, critics of GI protection can argue that although recognizable foods (and perhaps less ubiquitous ones) are similarly known by consumers as having historical origins in a specific region of

87. Barham, supra note 44 , at 129 .

88. Id. It is important to note that many wine enthusiasts would object to equating a GI with a product's terroir: a GI is broader than the extremely limited microclimate and soil delineations used to denote terroir.

89. Rovamo, supra note 70 , at 8 .

90. Id. at 9 .

91. Barham, supra note 44 , at 131.

92. Molly Torsen, Apples and Oranges (and Wine): Why the International Conversation Regarding Geographic Indications Is at a Standstill, 87 J. PAT. \& TRADEMARK OFF. SOC'Y 31,45 (2005).

93. Lori E. Simon, Appellations of Origin: The Continuing Controversy, 5 NW. J. INT'L L. \& BUS. 132, 151 (1983). 
geographical importance, they also have a new reality of production elsewhere in the world. ${ }^{94}$ Consequently, as a cultural matter, it would not only be pointless, but even anathema for the French or Danish to seek GI protection within the United States for products like "French dressing" and "Danish pastry." 95 The question of where the line of GI protection remains is a gray area of the law. Many terms like "sherry" and "port" are widely, but not universally, recognizable inside the U.S. market by the average consumer without any knowledge of the geographic history of these products. ${ }^{96}$ The United States is unlikely to ever protect "cultural hand-me-downs from early European immigrants"97 and, as one critic asks, what would we name many of these products if producers were forced to rename products that were suddenly given GI protection products?98 Consider, for example, Budweiser, as mentioned previously. What could Anheuser-Busch call their beer if a GI protection was granted today? Consider, for example, if Spain was able to gain GI protection for sherry, which originates from the Jerez region in Southern Spain. What would U.S. producers of essentially identical products then call the spirit? This may be, in a practical sense, the most important question.

\section{LOOKING INWARD AND To THE PAST TO Mitigate FUtURE PRoBlemS}

\section{A. "J'accuse...!"99 The Accusations Made Among Powerful Trading Partners}

Former European Union Agricultural and Rural Development Commissioner, Franz Fischler, once said, "EU producers are losing billions a year because non-European producers are free-riding on the reputation of European-quality products." ${ }^{100}$ Chairman of the U.S. House Agricultural Committee, Rep. Bob Goodlatte, R-Va., responded to the claim, quipping, "I'd say 'baloney,' but you realize that's a name they want back, too."101 European advocates cite benefits of GI protection that are especially visible in highly marginalized agricultural sectors,

\footnotetext{
94. Id. at 151.

95. Id.

96. See id. at 140 n. 46.

97. James Cox, What's in a Name?, USA ToDAY, Sept. 9, 2003, at 1B.

98. Id.

99. For the famous open letter criticizing the French government during the Dreyfus affair, see generally, Émile Zola, J'accuse...! Lettre au Président de la République ("I accuse...! Letter to the President of the Republic"), L'Aurone, Jan. 13, 1898, http://www.dreyfus.culture.fr/en/pedagogie/pedago-niveau-8-lettre-ouverte-au-president.htm.

100. Cox, supra note 97.

101. $I d$.
} 
particularly where the GI supports rural development. ${ }^{102}$ The United States, on the other hand, has accused European labeling restrictions as being protectionist and has expressed concern that European naming requirements would create a slippery slope to increasingly stringent restrictions on American goods. ${ }^{103}$

Similar fights have been fought within the United States; advocates of domestic appellation protection have cited the free-rider argument in an effort to monopolize wine branding. ${ }^{104}$ After the Bronco Wine Company bought smaller Napa brand-name wineries and exploited a loophole allowing the company to label its wine as "Napa" without using Napa grapes, some wine producers in the Napa Valley pushed for legislation to prevent the outside use of the Valley's valuable appellation. ${ }^{105}$ Federal regulations allow the use of a viticultural area appellation if no less than eighty-five percent of the grapes in the wine are grown within the boundaries of that geographical area. ${ }^{106}$ Napa Valley is a protected viticultural area with definable and finite boundaries. 107 However, there is a provision in the regulations exempting "brand names in existing certificates of label approval issued prior to July 7, 1986." 108

Attempts at state legislation protecting the appellation have since been unsuccessful, with California law only requiring that the use of an appellation designating a political subsection of the state involve the use of only California-grown grapes. ${ }^{109}$ One proponent of state legislation said, "There's a very strong relationship between the quality of wine and the place where it is grown. Wines are of a place, unlike corn flakes. Corn is corn, but grapes are not grapes." 110 Opponents of state legislation contend that protective legislation only benefits the Napa growers, and that legislation would put artificial, upward pressure on the price of Napa grapes to the detriment of consumers and other

102. Barham, supra note 44 , at 128 .

103. William Echikson, Politics \& Economics: U.S., EU Sign Wine Pact Ending 20-Year Dispute, WALL ST. J., Mar. 11, 2006, at A4.

104. Mitchel Benson, Napa Vintners Push to Protect Their Name, WALL ST. J., June 28, 2000, at CA1.

105. Id.

106. 27 C.F.R. $\S 4.25(\mathrm{e})(3)(2011)$.

107. See 27 C.F.R. $\$ 9.23$ (2011) (detailing the codified geographic boundaries of Napa Valley).

108. 27 C.F.R. § 4.39(i)(2) (2011).

109. CAL. CODE REGS. tit. 17, § 17015 (2011).

110. Benson, supra note 104. 
producers. $^{111}$ However, with a valuable slice of the California wine market at stake, the free-rider concerns remain unresolved. ${ }^{112}$

\section{B. Alternatives to California "Champagne": The United States' Interest in Domestic Label Protection}

California sparkling wines are gaining a commendable reputation, with French firms producing many superior wines with grapes of French origin that are grown and processed in California. ${ }^{113}$ Wine giant Moët et Chandon uses French "technology, equipment, and skills"-a valuable trifecta in the creation of champagne-style wines-in the firm's California vintages. ${ }^{114}$ However, despite using French-origin grapes and techniques, the firm refuses to call its U.S.-produced wine "champagne." 115 Nevertheless, according to director of the champagne section of Moët et Chandon's parent company Société Moët Hennessy, the wine, under the label "sparkling wine"-as would be required under French law-"will be of top quality."116

California vintners are not only capable of creating quality wines, they sometimes even trump their French equivalents. ${ }^{117}$ With California firms producing quality goods, the reader may ask why it would be necessary for California wines to piggyback on the good name of their champenoise counterparts rather than develop independent branding. Sparkling wines, even using names other than champagne, are now competitive in the marketplace and are beginning to rival the French original in terms of quality and consumer appeal. ${ }^{118}$ Even though the French have essentially been estopped from seeking name protection because of their long-standing failure to closely guard the trade name, ${ }^{119}$ it may behoove U.S. champagne producers to seek other alternatives to naming their wines "champagne," such as compromises similar to those the United States has made in the past in order to protect the United States Bourbon industry and the compromises Australia made to create a now booming wine industry.

111. Id.

112. $I d$.

113. Terry Robards, Champagne Wars, N.Y. TIMES, Oct. 31, 1982, at SM78.

114. Id.

115. Id.

116. Moet Will Make California Wine, N.Y. TIMES, Apr. 25, 1973, at 32.

117. Prial, Wine Talk, supra note 79.

118. See Frank J. Prial, Sparkling Alternatives, N.Y. TiMES, May 6, 1984; at F34.

119. Id. 


\section{Success with Previous U.S.-France/EU Compromises: Bourbon and Table Wine}

The United States enjoys a competitive advantage in generics because the country can take advantage of liberal, domestic labeling laws when exporting products, while allowing other countries, such as France, to restrict their own exports because of exacting labeling laws. ${ }^{120}$ However, the United States has agreed to strict labeling agreements when they serve the country's domestic economic interests. ${ }^{121}$ In a bilateral treaty, the United States and France agreed that France would protect the terms "Bourbon" and "Bourbon Whiskey" if the United States would protect the names "Cognac," "Armagnac," and "Calvados" to the benefit of the French. ${ }^{122}$ Having recognized the economic value in preventing Bourbon from becoming a generic trade label (in the manner the United States approaches the term "champagne"), the United States made the bargains necessary to prevent genericide of a valuable domestic product name. The term "Bourbon" had the potential to come to refer to all whiskeys in general; now, at least in France, that process of genericide has been terminated and the Bourbon name is legally protected.

The United States has also made concessions to the GI recognition of many European table wines, such as Castilla y León, Toscano, and Bayerischer Bodensee, ${ }^{123}$ in exchange for protection of American winemaking practices not otherwise allowed in the European Union. ${ }^{124}$ Very importantly, the United States agreed to discontinue the export of "California Champagne" if the European Union recognized the United States' practice of adding oak chips to wine barrels, an important component of the popular oaked chardonnay. ${ }^{125}$ This practice is forbidden in the European Union, thereby giving the United States an effective monopoly on the process and the product's import into the European Union. ${ }^{126}$ Evidence suggests that the United States is willing to make sacrifices and compromises when there is an economic interest in doing so. For example, the United States may be willing to make further concessions in order to protect the American wine varietal,

120. Simon, supra note 93 , at 153.

121. Id.

122. Exchange of Notes Constituting an Agreement for the Protection of Names of Bourbon Whiskey and Certain French Brandies, U.S.-Fr., opened for signature Dec. 2, 1970, 777 U.N.T.S. $77,80-81$.

123. Agreement Between the United States of America and the European Community on Trade in Wine, U.S.-EU, Mar. 10, 2006, 2006 O.J. (L 87) 1, at art. 7.

124. Id. at art. 4.

125. Echikson, supra note 103.

126. Id. 
"zinfandel"- a wine with a particular cultural significance in the United States. ${ }^{127}$

\section{Success in the Emerging Australian Wine Market}

Australia has experienced an undeniable benefit in the international wine trade resulting in part from its expansion of GI protection. ${ }^{128}$ Following a 1994 agreement between Australia and the European Community on the protection of wine names, ${ }^{129}$ Australian winemakers were able to protect their regional names and stress the diversity of their products. 130 Undoubtedly, in part because of this, Australian wine exports to the United States have increased drastically from 1994 to the present. ${ }^{131}$ The current Australia-EU agreement from $2008^{132}$ continues to provide name protection for both Australian and European wines. ${ }^{133}$ These protections also extend to the use of names of regional significance, both when the true origin of the wine is given and when expressions such as "kind" or "like," are used.134 This, in effect,

127. See Zinfandel Growing Regions, ZinfandeL ADVoc. \& ProducErs, http://www.zinfandel.org/default.asp?n1=2\&n2=174\&member=. (last visited Oct. 8,2012 ) (showing Zinfandel-growing regions in California). This varietal is so important to some vintners that a not-for-profit organization has been created to "keep the story and significance of Zinfandel and its rich heritage in California alive and vibrant." Overview Of $Z A P$, ZINFANDEL ADVOC. \& PRODUCERS, http://www.zinfandel.org/default.asp?n1=3\&mem ber= (last visited Oct. 8, 2012). Although Zinfandel Advocates \& Producers was not formed to protect the economic interests of the zinfandel varietal, in the author's opinion, the organization's existence demonstrates that there may be, in fact, an interest in protecting the varietal's name abroad.

128. See Irene Calboli, Expanding the Protections of Geographical Indications of Origin Under TRIPS: "Old" Debate or "New" Opportunity?, 10 MARQ. INTELL. PROP. L. REv. 181, 200 (2006).

129. Agreement Between the European Community and Australia on Trade in Wine, Austl.-E.U., opened for signature Jan. 24, 1994, 1994 O.J. (L 86) 3.

130. See Calboli, supra note 128, at 201.

131. For a discussion on how "country of origin advertising" affects the wine trade, see generally STANLEY R. THOMPSON \& ABDOUL G. SAM, COUNTRY OF ORIGIN ADVERTISING AND U.S. WINE IMPORTS (2008), available at http://ageconsearch.umn.edu/bitstream/6553 $12 /$ sp08th01.pdf. It is worth noting that Australia has seen a slight decrease in wine production and export in recent years. See Australia, Wine Annual, 2012 Wine Annual, USDA FOREIGN AGRICULTURAL SERVICE GAIN REPORT (March 15, 2012), at 3, available at http:/gain.fas.usda.gov/Recent\%20GAIN\%20Publications/Wine\%20Annual_Canberra_Aus tralia_3-14-2012.pdf. This is in part because of heavy rains that have limited Australia grape production and the strength of the Australian dollar relative to currencies of other foreign markets. $I d$. at 2,5 .

132. Agreement Between the European Community and Australia on Trade in Wine, Austl.-E.U., Dec. 1, 2008, 2009 O.J. (L 28) 3.

133. Id. art. 12.

134. Id. art. 13(3)(a)-(c). 
prohibits Australia from calling an Australian wine "champagne-like."135

The United States may have reason to fear that, if it were to follow Australia's example, consumers would purchase more expensive, well-known brands like French champagne because of consumer beliefs that price is a good indicator of quality. ${ }^{136}$ Making an Australian-style concession to the European Union, on the other hand, would provide American wines "long-term access to European markets," an especially important market when U.S. exports in wine are rapidly growing. ${ }^{137}$ Furthermore, European recognition of American appellations could protect uniquely American wine exports, which may be helpful if there is a decline in domestic wine consumption in the future. ${ }^{138}$ If there were bilateral protection of appellations, perhaps Europeans would be more willing to purchase U.S. exports as a result of newfound goodwill among the countries. As with the trade in Bourbon, the United States will likely only make such a concession when there is economic incentive to do so. However, given the global success of the Australian wine industry, there may be benefits to investigating what measures the United States can take to protect its economic interest while also appeasing its trade partners. For example, perhaps increased protection in the United States for the term "champagne" (or other European appellations) could result in the protection of "zinfandel."

\section{CONSIDERING THE FUTURE: WHAT TO Do ABOUT ZINFANDEL?}

\section{A. Feasible Compromises Are Not Yet Forthcoming}

In the United States, liberal naming conventions allow champagne producers to call products "champagne type" (or myriad variants) even when the wine is not produced according to the "champagne method."139 If the United States were to restrict the term "champagne" to only those products fashioned in the champagne method, United States wine

135. Id.

136. Zacher, supra note 47 , at 461.

137. Echikson, supra note 103.

138. See Howard G. Goldberg, Winery Wants 'Pacific Coast' Appellation, N.Y. TIMES, June 26,1991 , at $\mathrm{C} 8$.

139. 27 C.F.R. $\S 4.21$ (b)(3)(i) (2012). There are many methods of producing sparkling wine. Prosecco, an Italian sparkling wine, for example, is produced using the Charmat method. See Tom Hyland, The Charm of Prosecco, wINELOvERSPAGE.Com (July 12, 2002), http:// www.wineloverspage.com/italwineguide/prosecco.phtml, and Stacy Slinkard, Charmat Method, ABOUT.COM, http://wine.about.com/od/vineyardvocab/g/charmatmethod.htm (last visited Oct. 8, 2012), for further discussion of the Charmat method and background on Prosecco wine. 
producers could still use the term "champagne" freely, but only in instances where the champagne was bottled in a traditional French manner, rather than when using the Charmat method-the method by which wine undergoes its secondary fermentation in a bulk process rather than in individual bottles. ${ }^{140}$ Although this may not be an ideal compromise for France, restrictions of this type are more likely to be implemented than a complete ban on the name for American producers.

Compromises that harmonize intellectual property law will reduce trade barriers and positively affect economic growth. ${ }^{141}$ TRIPS protections aim to protect consumers by providing accurate labeling information and help to "enabl[e consumers] to make informed choices between various goods and services." 142 But because American and European wine producers differ on their views on genericide, compromise will be difficult because "the E.U. is losing money with the status quo, and the United States would lose money if the current system were to change."143 To resolve the issue, the United States could pay the European Union for the right to use protected GIs, or the European Union could pay the United States to comply with more restrictive laws. ${ }^{144}$ However, this suggestion is cost prohibitive. ${ }^{145}$ Indeed, neither party would be willing to write the check, nor would the other party be willing to cash it, as doing so would equate to an ideological and moral defeat. ${ }^{146}$

\section{B. The Case for Advancing Cooperation to Protect U.S. Goods: Zinfandel-A Case Study}

Despite the appearance of a stalemate, the United States does have a current incentive to cooperate with other countries in order to harmonize this segment of intellectual property law. I suggested earlier in this note that the United States may have an economic justification in protecting Zinfandel-a uniquely "American" varietal. Just as France may have cultural and economic reasons to protect the champagne label, a growing appreciation for the cultural and viticultural significance of Zinfandel in the United States may merit further legal protections for this American wine.

140. See Charmat discussion, supra note 29 .

141. See Zacher, supra note 47 , at 449.

142. Id.

143. Id. at 459 .

144. Id.

145. Id. at 462.

146. Id. 
The zinfandel varietal's origins have been traced to the "Crljenak Kaštelanski" vine from the Croatian coast and the genetically identical grape has been found in Puglia, Italy, where it is known as "Primitivo."147 In a Stanford University working paper, Dr. Ryan P. Kelly, wrote that, "With standard genetic tools, California zinfandel can be matched against each putative synonym to substantiate historical or ampelographical data. This has been done for both Italian primitivo and Croatian crljenak kastelanski, and overwhelming data show that the different names refer to the same genetic stock." 148 Although genetically similar, the wines produced from U.S. zinfandel and Italian primitivo grapes exhibit "clonal differences [that] may produce characteristically different wine. . . Over many years of growth as free-living plants, these clones may have developed somatic differences that could differ from plant to plant." 149 While U.S. law does not view primitivo and zinfandel as synonyms for the purposes of labeling U.S. produced wines, ${ }^{150}$ a $1998 \mathrm{EU}$ Commission Regulation allows Italian vintners to label primitivo wines with the zinfandel name. ${ }^{151}$ Should Italian vintners choose to label primitivo wines as a zinfandel-even though those wines exhibit differences in their viticultural expressionslabeling laws allow Italian wine producer to do so.

The Association of Zinfandel Advocates and Producers (ZAP) is a California-based 501(c)(3) organization dedicated to "elevat[ing] the understanding and status of Zinfandel wine" and "provid[ing] funding for education and research to study the history, genetics and propogation of [the zinfandel] varietal to ensure its future."152 In a partnership with the University of California at Davis, ZAP supports the Zinfandel Heritage Vineyard Project, "an unprecedented collection of rare and famous Zinfandel vine cuttings grown throughout

147. Transformation Creates New Tradition, The History of Zinfandel, ZINFANDEL, ADVOC. \& PRODUCERS, http://www.zinfandel.org/uploads/STMD\%20Divide-HistoryZin_06C.pdf (last visited Aug. 17, 2013).

148. Ryan P. Kelly, The Science of Wine Varietal Labeling Regulations: The Cases of Zinfandel and Petite Syrah, Stand University-Center for Ocean Solutions (working paper), Dec. 1, 2010, at 2, available at http://papers.ssrn.com/sol3/papers.cfm?abstract_ id $=1763380$.

149. Id. at 5-6.

150. 27 CFR $\S 4.91$ (2012) ("When more than one name may be used to identify a single variety of grape, the synonym is shown in parentheses following the grape variety names.")

151. Commission Regulation (EC) No. $2770 / 98$ of 21 Dec. 1998, at 2, available at http://eur-lex.europa.eu/LexUriServ/LexUriServ.do?uri=OJ:L:1998:346:0025:0028:EN:PDF.

152. Overview of $Z A P$, ZINFANDEL ADVOC. \& PRODUCERS, http://zinfandel.org/default.asp?n1=3\&member= (last visited Sept. 21, 2013). 
California."153 It was through the Heritage Vineyard Project that University of California researchers found the zinfandel grape's origins started along Croatia's Dalmation coast; ${ }^{154}$ however, ZAP notes that the wine has "established its own tradition in California and has become America's Heritage wine." 155

Rebecca Robinson, ZAP's Executive Director, leads wineries and consumers alike in an effort to promote the zinfandel varietal domestically and internationally. ${ }^{156}$ In a telephone interview I conducted with Ms. Robinson, she explained some reasons why zinfandel is of cultural and historical importance to the United States, and most specifically, to California. ${ }^{157}$ Robinson commented on how zinfandel has a history and legacy that allowed the varietal to compete on a world stage from as early as the 1880 s. ${ }^{158}$ She went on to say, paraphrasing a colleague:

Had Prohibition not interrupted the winemaking culture, industry, business in California there would be no question that zinfandel would have been established as the benchmark varietal for California in terms of its prominence. . . . With zinfandel, there is no other benchmark for that varietal other than [in] California. When you talk about cabernet sauvignon or pinot noir, you know that the benchmark for that wine is in France. . . We don't have that for zinfandel; zinfandel is California's benchmark wine. ${ }^{159}$

Robinson advances an idea that shares common ground with French wine advocates-that wines produced in specific territories can have historical origins that are not found elsewhere.

Zinfandel's viticultural history is especially unique for a grape found in the United States. The vine's persistence since the late 1800s has led,

153. Zinfandel Heritage Vineyard, The Project, Zinfandel ADVoc. \& Producers, http://zinfandel.org/default.asp?n1 = 18\&n2=787 (last visited Sept. 21,2013 ).

154. Transformation Creates New Tradition, The History of Zinfandel, ZINFANDEL ADVOC. \& PRODUCERS, http://www.zinfandel.org/uploads/STMD\%20Divide-HistoryZin_06C.pdf (last visited Sept. 21, 2013).

155. Id.

156. Executive Director, ZINFANDEL ADVOC. \& PRoDUCERS, http://zinfandel.org/default.asp?cid=1\&n1=2\&n2=168 (last visited Sept. 21, 2013).

157. Telephone Interview with Rebecca Robinson, Executive Director, Zinfandel Advocates \& Producers (ZAP) (March 27, 2013).

158. Id.

159. Id. 
in some instances for especially long-lived zinfandel vines, for some such wines to be called "old vine" wines.

Zinfandel is also unique in that we have some of the oldest living examples of grapes that are grown here in California. It's "old vine" zinfandel, you don't hear about "old vine cabernet" or "old vine chardonnay." It's "old vine zinfandel" and that's a unique characteristic of the varietal . . . these vines date back over a hundred years. 160

Unlike many other varietals grown in California, zinfandel has a comparatively long tradition of being produced in the area. Continuous production of zinfandel contributes to the unique historical tradition of the varietal in California's vineyards; ZAP and the Heritage Vineyard Project are attempting to preserve this heritage by creating a more diverse growing stock available to growers ${ }^{161}$ and by affording the public opportunities to learn about zinfandel's American history. ${ }^{162}$

Like wines found in various regions of France, there is a case to be made that California zinfandels have a terroir-a unique microclimate that contributes to the identity of the wine itself. Robinson commented on the role of terroir, saying:

California is so blessed in terms of its agricultural heritage and what we can do in so many different areas of CA for growing. When you taste [wines from various regions of California] side-by side, they have a distinct terroir, if you will. And that's again part of what we've been trying to document ... . but [if] you talk to five winemakers . . . you're going to get fifteen opinions on the influence of style and whether or not you've used California oak versus French oak, or whether you go through complete malolactic fermentation, or you stop short and leave a little residual sugar in the wine. . . I think that's one of the attractions of wine actually. . . It touches so many levels. It touches land, it touches culture, it touches the most basic of our needs, to sit

160. Id.

161. Zinfandel Heritage Vineyard, The Project, supra note 153.

162. ZAP's Mission, ZINFANDEL ADVOC. \& PRODUCERS, http://zinfandel.org/default.asp?n1=3\&n2=1\&member= (last visited Sept. 21, 2013). 
down and share community with each other when we have a meal together. ${ }^{163}$

However, even with regard to California wines, the "nature versus nurture" debate continues. Different regions produce wines with various flavor profiles, but man-made processes, for example aging or fermentation methods, can dictate many characteristics of a wine as well. Such variations are important and contribute to the diversity of the zinfandel varietal; but in the end, the wines are all still zinfandels.

The very existence of a nonprofit organization dedicated to the education and advocacy of a zinfandel shows a need to pause and consider United States wine labeling laws. Although ZAP is a 501(c)(3) and is prohibited from lobbying or attempting to influence legislation, 164 I argue that ZAP's position that there is reason to educate the public on the distinctive cultural history of zinfandel in the United States merits a reevaluation of the value of uniquely American products in domestic and international legislation. When commenting on how ZAP has helped zinfandel's growth, influence, and brand recognition throughout the global wine community, Robinson said:

Since ZAP started twenty-two years ago, there has been an absolute explosion in the number of wineries. . . I I think that the market has become much more sophisticated in so many ways, and again this follows somewhat of a trend that we see throughout industries. You've got a more discriminate consuming public; you've got access to more information now.

When the organization first started, white zinfandel was regarded as "zinfandel" because of the great popularity. of white zinfandel, which was fantastic; that was a great phenomenon, it certainly was a boost to the industry. It was a wonderful and sensible wine for consumers, but it didn't tell the whole story of zinfandel. It certainly points to its diversity: it can be a nice light-bodied pink wine, but it didn't really address the quality issue, the historical issue, the diversity of zinfandel in terms of the style or the terroir. So that really had to be addressed.

163. Rebecca Robinson Telephone Interview, supra note 157.

164. 26 USC § 501(c)(3) (2012), "no substantial part of the activities of [the organization] is carrying on propaganda, or otherwise attempting, to influence legislation." 
When you said zinfandel were you going to get a pink wine or were you going to get a red wine? Now, most consumers who start to get into wine, and into exploring wine, they recognize "Oh! Zinfandel is a red wine." But again, in terms of the knowledge base, of understanding "why is it I like this particular wine from Sonoma County?" and "what are the characteristics of that wine as compared to tasting a wine from the central coast of Paso Robles?" where . . . it's got somewhat similar characteristics but it's got a different flavor profile and so "what it is about that?" and "why do I like one over the other?" and "how does it pair with food?"165

The growth of the Zinfandel brand over the past decades indicates an ever-increasing economic incentive to protect the varietal's labeling protection. Furthermore, more widespread educational resources, such as those ZAP provides, makes the term "zinfandel" more and more valuable to United States vineyards. With increased popularity, and having exhibited characteristics such as a unique cultural heritage and distinctive terroir in the United States, I propose that zinfandel demonstrates the qualities that deserve legal protection in international intellectual property law. Zinfandel demonstrates that a uniquely American product does in fact deserve legal protection, and that the economic incentives do actually exist to move this area of law forward toward global harmonization.

\section{CONCLUSION}

The status quo may not offer the best long-term solution for the United States, even though free trade seems a superior alternative to the specter of protectionism many accuse the European Union of encouraging. ${ }^{166}$ However, as the United States develops an economic interest in protecting its domestic industries, such as that of zinfandel, the likelihood that the United States will seek GI protection for its unique and distinctive products increases. Just as the United States benefits from the use of generics, foreign competition may soon use U.S. appellations in an effort to take advantage of the growing reputation of American wines. ${ }^{167}$

165. Rebecca Robinson Telephone Interview, supra note 157.

166. Simon, supra note 93 , at 155 .

167. Id. Worldwide recognition of American vintages is often famously attributed to the 1976 "Judgment of Paris," where two California wines outranked French counterparts in a blind taste-test competition. Thane Peterson, The Day California Wines Came of Age, 
The United States, having an advantage in the use of generics, will be reluctant to give up its interest in foreign appellations without significant economic incentives. While this may be the case, the United States must also recognize that such economic justifications for GI protection exist and that solutions, like the Bourbon treaty, are readily available to protect not only the zinfandel industry, but potentially many other unique sectors that merit labeling protection. As developed and developing ${ }^{168}$ countries attempt to standardize their intellectual property laws, the United States must ask when it will do the same. Until then-and only upon the United States' recognition that GI protection is in the country's best interests-the controversy will remain at a standstill and the status quo will be preserved.

BLOOMBERG BUSINESSWEEK (May 7, 2001), http://www.businessweek.com/stories/2001-05. 07/the-day-california-wines-came-of-age. In a "rematch" thirty years later, the California wines still beat out the French. Alder, The Re-Judgment of Paris Results in California Landslide, VINOGRAPHY: A WINE BLOG (May 24, 2006), http://www.vinography.com/arch ives/2006/05/the_rejudgment_of_paris_result.html.

168. For a case study on the potential protection of the Indian "Darjeeling" tea appellation, see S.C. Srivastava, Protecting the Geographical Indication for Darjeeling Tea, in Managing the Challenges of WTO Participation: 45 Case Studies 231 (Peter Gallagher et al. eds., 2005), available at http://www.wto.org/english/res_e/booksp_e/case studies_e/case16_e.htm. 
